\title{
The Arabic Grammatical Tradition
}

\author{
Kees Versteegh
}

I N THE 1960s, the curriculum of a thirty-three-hour week for a senior student at a Dutch grammar school included twelve hours of Latin and Greek, nine hours of French, German, and English, and four hours of Dutch. In the curriculum of grammar schools all over Europe, the classical languages similarly predominated. Those languages were taught in much the same way that Latin had been taught in the Middle Ages, by reading and translating texts, in what has become known as the grammar-translation method. Language learning amounted to the memorization of grammatical rules. Lexical knowledge was acquired by learning those words that occurred in the texts. To some extent, the modern languages were taught in the same way: lessons in English, French, and German focused on translating texts into Dutch. After six years, students became highly skilled in decoding complicated texts, while hardly ever using any foreign language productively. ${ }^{1}$

Learning a classical language like Latin or Greek does not confer any communicational advantage on students, even though such languages might be useful for any number of religious, political, or scholarly reasons. Throughout history, learned languages formed part of education in many civilizations, from Sumerian in the Akkadian world to Latin in medieval Europe, from Greek in ancient Rome and the Hellenistic world to Sanskrit in Southeast Asia, from Chinese in Japan to Classical Nahuatl in the Aztec Empire. ${ }^{2}$

The value a society places in the acquisition of a particular learned language is a crucial factor in the language becoming an established part of the school curriculum. In some cases, acquiring a learned language is seen as the marker of a privileged class and the means by which a student joins an intellectual elite. Mastery of the learned language demonstrates, at a minimum, that a student has learned to read and write, but also grants them access to the body of knowledge recorded in that language. Once established, the customs associated with a learned language can persist for long periods. Having dedicated themselves to learning a language and endured the rigors of the school system, students can hardly be expected to disparage the effort afterwards. Similarly, students can also hardly be expected to waive such requirements for their successors to join them in an intellectual elite.

In large parts of the Islamic world, the learned language children are taught at an early age is Classical Arabic, the language of the Qur'an as well as the language of knowledge and scholarship. Religion may constitute a major reason for investing so much energy in learning Arabic, but it is by no means the only one.

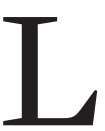

ONG AFTER THE FALL of the Roman Empire in $476 \mathrm{CE}$, Latin continued to serve as the learned language of Western Europe. It was the language of writing and formal speech, while the colloquial Romance languages that had sprung up throughout the empire were used in informal communication. This type of sociolinguistic situation is known as diglossia. A similar situation arose in the Arabic-speaking world. In the course of the Islamic conquests from $632 \mathrm{CE}$ onward, Arabic was introduced throughout the Middle East and North Africa. The language of the Qur' an became the written standard of administration, literature, and education, while colloquial varieties, usually called Arabic dialects, developed along with it. It is still the case that the local Arabic dialect is acquired as a first language, while the prestigious standard language is acquired in school. Although the Arabic dialects are as different from Classical Arabic as the Romance languages are from Latin, there is an enduring fiction that the colloquial language is, in fact, identical with the standard language and that school children are native speakers of the learned variety. This is not the case. For explanations of the texts, students remain heavily reliant on the colloquial language.

Within the Arabic-speaking world, some areas remained bilingual, such as the Berber-speaking Sous in Morocco. From the sixteenth century onward, the Berber-speaking Sous created a flourishing literary tradition, in which the local language, Berber, was used as an auxiliary language in teaching Arabic. Berber served as the means of communication between teachers and students, and it was the language in which the Arabic texts were explained, commented on, and paraphrased, and in which textbooks for beginners were written. ${ }^{3}$ Yet it was not a language that 
needed to be learned for its own sake. The proficiency of students was taken for granted.

In the course of Islamization following the initial period of conquests, Arabic was spread as a written language in sub-Saharan Africa, as well as Central, South, and Southeast Asia. Teaching of Arabic focused on the transmission of texts, chief among them the Qur'an. At school, texts written in the learned language were explained in the local language-Persian in Iran, Swahili in East Africa, and Malay in Indonesia. Knowledge of the local language by the students was assumed and not part of formal training.

Teaching a learned language relies on understanding written texts, although this does not necessarily imply that students are able to speak the language outside a formal setting. Most people, even in countries with Arabic dialects, were unable to extemporize in the standard language, and switched to colloquial Arabic whenever they could. In regions with non-Arabic native languages, oral use of standardized Arabic was even more restricted. In West Africa, it was used as a diplomatic language between political entities, which entailed a certain level of proficiency. In the fourteenth century, cities such as Timbuktu became academic centers of learning, where Arabic was used both in writing and in formal scholarly debates. In East Africa, a lively literary culture developed in the eighteenth century in Lamu Island off the coast of Kenya where both Arabic and Swahili (in Arabic script) were used in writing, but oral discussions tended to take place in Swahili.

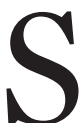
URPRISINGLY LITTLE IS KNOWN about the everyday practice of primary education in the early history of the Arabic linguistic tradition. Children learned the principles of writing and reading in a type of school known as a kuttāb or maktab, from a schoolmaster who taught them to write and recite the Qur'an. In the ninth-century work Kitāb ādāb al-mu'allimīn (Rules of Conduct for Teachers), Ibn Sahnūn proffers advice about the curriculum, recommending a broader selection of reading materials than just the Qur'an, including poetry and pre-Islamic history. ${ }^{5}$ Like Ibn Sahnūn, the fourteenth-century historian Ibn Khaldūn argued against the exclusive emphasis on the text of the Qur' an in language teaching. In his sketch of education in the Maghreb, he calls for the development of communicative skills in children, rather than the memorization of grammatical rules. ${ }^{6}$ The impact of these views in daily classroom practice is unknown, but they do not seem to have led to major changes in the grammatical treatises used in teaching.

After the kuttāb, only a small percentage of children went on to attend lessons in a madrasa, usually connected with a mosque, where they learned the basics of the Islamic sciences. In language studies, these students started with elementary grammars, sometimes in the form of a catechism with questions and answers, which had to be memorized. The end of the curriculum was marked by the memorization of a text summarizing the grammatical rules, such as the thirteenth-century 'Alfiyya, a thousand-line grammatical poem by Ibn Mālik.

Students who opted to study language went on to attend private lessons with a grammarian. The customary form of teaching was for the teacher to read a treatise aloud, while the students transcribed the text. Alternatively, the teacher had the students recite text from a manuscript, while the teacher assessed its correctness, working from memory. This process was accompanied by oral explanations from the teacher, clarifying obscure points.

Some students later published a commentary on the text they had read with their teacher, in which they reported on questions asked and answers received during the lessons. Such exchanges can be found in the first complete Arabic grammar, composed by Sïbawayhi in the eighth century and simply referred to as Kitäb Sỉbawayhi (Sỉbawayhi's Book). His main teacher was al-Khalīl ibn Ahmad, author of the first largescale dictionary of Arabic. The intensive interaction between them is illustrated by the almost 600 quotations from al-Khalī's teaching in the Kitāb, far more than from any other grammarian. Sỉbawayhi asks his teacher about the interpretation of difficult passages from the Qur' an, but also about made-up sentences, many of which turned around the proper declensional endings. In one typical example, Sībawayhi constructs the sentence "I passed Zayd and his brother came to me, both of them," and asks al-Khalīl about the correct case ending for "both of them," which serves as an apposition to two different constituents in the sentence.

Grammarians from rival schools occasionally met in a formal session, or majlis, in which they discussed grammatical questions, accompanied by their students. Reports about these sessions present the grammarians bombarding each other with lines of poetry and Qur' anic verses and challenging the knowledge of their opponents concerning the lexicon and grammar. Debates sometimes grew heated, grammarians having a reputation for being short-tempered and combative. Students attended these meetings in order to support their teachers and to learn the art of defeating an opponent by superior knowledge of the rules and of the main sources of written Arabic: the Qur' an and poetry.

\footnotetext{
A RABIC GRAMMATICAL TREATISES were never meant to be grammars for learners. Such treatises start from the assumption that native speakers of Arabic knew how to speak and did not need a description of their language, let alone a prescriptive grammar telling them how to speak correctly. Yet these idealized native speakers were not credited with any theoretical insight into the rules, and this is where the grammarians came in. Their task was to apply a theoretical framework to the grammatical phenomena, explaining the reasons behind the rules.
} 
In his work al-'ị̂ăh fì 'ilal al-naḥw (The Elucidation of Grammatical Causes), the tenth-century grammarian al-Zajjāji makes a systematic distinction between three levels of grammatical explanation. Anyone wishing to learn a language needs to know the rules, but not everyone needs a detailed explanation. Accordingly, textbooks of the first level only state the main rules of grammar, for instance that the affirmative particle 'inna (indeed) is followed by the topic of the sentence in the accusative case and the predicate in the nominative case. When this particle is introduced into the sentence zayd-un tawīl-un (Zayd is tall), in which both topic and predicate have the nominative ending -un, the sentence becomes 'inna zayd-an tawìl-un (indeed, Zayd is tall), in which the topic zayd has the accusative ending -an. At this level, no further explanation is needed. Almost from the beginning of the Arabic tradition, grammarians published brief first-level treatises without theoretical explanations. ${ }^{8}$ Al-Zajjājī himself wrote such a treatise summarizing the grammatical rules, entitled al-Jumal (The Compendia), which became highly popular.

Treatises of the second level provide explanations by formulating the rules in terms of grammatical governance. This theory stipulates that all declensional endings are produced by a grammatical operator. In the sentence cited above, the operator is formally identified as the particle 'inna. The action of this particle is explained by its resemblance to a verb, which enables it to operate on the topic and the predicate, just like the verb operates on the agent and the object. The theory of governance pervades the entire system of Arabic grammar, and grammarians view it as their core business to determine the operator of each and every declensional ending.

Third-level grammatical treatises probe the reasons behind the second-level explanations. When asked, for instance, why the accusative ending contains an $a$, while the nominative ending contains a $u$, a grammarian might answer that, since the accusative is more frequent, it is represented by the vowel $a$, which is the vowel pronounced with the least physical exertion. Principles such as euphony, ease of articulation, frequency of usage, and natural order are adduced at this level of argumentation. This is the level to which al-Zajjājī dedicated his İ

It would be wrong to assume that the pedagogical grammars of the first level aimed to simplify grammar for the benefit of language learners. There was no reduction in the number of rules. Rather, they taught the same grammatical rules, but omitted the explanations proposed in advanced grammar lessons. Pedagogical grammars remained just as rule-based but presented the rules in such a way that they could be memorized more easily.

$\mathrm{I}$

T IS ONE THING TO LEARN the rules by heart, and quite another to handle them the proper way. The attendance of students at a majlis acquainted them with the way grammatical arguments are used in a debate, but they prepared for this practice beforehand through a strict regime of exercises. Remaining sources do not contain a systematic record of the exercises given to students, but a considerable number of isolated examples can still be found. One of the first things students had to grasp was the special nature of the Arabic lexicon. Like most Semitic languages, Arabic has a nonconcatenative word structure, which means that it is usually possible to distinguish within a word three-or sometimes four or five-root consonants or radicals, containing the semantic information. These root consonants are inserted into a template denoting the morphological and syntactic features of the word by a specific constellation of vowels and auxiliary consonants. The root $k-t-b$, for instance, is connected with the notion of writing. It occurs in different templates, producing words such as kataba/yaktubu (he wrote/writes), 'aktaba/yuktibu (he made/makes someone write), kitäb/kutub (book/books), maktab/makātib (office/offices), kātib/kuttāb (writer/writers), takātub (correspondence), iktitāb (subscription), and dozens more.

At an early stage, grammarians came up with a way of formally encoding the template by representing the root consonants with the consonants $f$, ', and $l$, and inserting these into a template. This innovation is sometimes associated with the grammarian $\mathrm{Mu}$ 'ādh al-Harrā' of the eighth century. Thus, kitāb was encoded as fi 'äl, maktab as maf'al, yuktibu as yuf'ilu, iktitāb as ifti 'âl, kuttāb as fu' 'āl, and so on.

In the case of the root $k-t-b$, the derived words in the different templates are morphologically transparent. But in roots containing a glide (such as $w, y$, 'alif), ${ }^{9}$ a glottal stop, or a geminated consonant, phonotactic rules like elision and assimilation may obscure this transparency, making it difficult to recover the root consonants.

Modern psycholinguistic studies have been concerned with the question of whether Arabic speakers are aware of the roots, given that the relationship between root and actualized word is sometimes opaque..$^{10}$ Since in a large number of words the relationship is transparent, one expects speakers to be aware of the root in a considerable number of cases. Indeed, evidence from instances of metathesis in aphasic speech, wordplay, and slips of the tongue in Arabic suggests that what gets shuffled are the root consonants, never the auxiliary consonants of the template. In a word like maktab (office), with the root consonants $k-t-b$, errors are likely to include matkab and mabkat, but not tamkab. ${ }^{11}$

An additional argument for the organization of the lexicon by roots is that the grammarians set great store by students' ability to extract the root consonants from a given word. One exercise involved using a root in a particular template. In one instance, $\mathrm{Mu}$ 'ādh al-Harrā' challenges someone with the question "How do you say 
$y \bar{a}$ fă' ilu 'if al from ta'uzzuhum 'azzan (they are confusing them) [Qur' an 9/83]?" The aim of this exercise is to derive the active participle ( $f \bar{a}$ 'il) and the imperative ('if'al) from the root ' $-z-z$, forcing the student to apply basic phonological rules. ${ }^{12}$

In the tenth century, the grammarian Ibn Jinnī used imaginary roots to train students in applying the rules. ${ }^{13}$ In one example, he asks them to imagine a root consisting of four glottal stops, and then to apply to this root the uncommon template 'uf'ulla of the word 'utrujja (lemon), which produces ' $u$ " 'u" $a$. This form is affected by various phonotactic changes. First, a change ' $>w$ affects the first and the third glottal stop, resulting in /'uw'uwa/, phonetically realized as ' $\bar{u}{ }^{\prime} \bar{u}^{\prime} a$. Then, the remaining glottal stops undergo lenition, $w^{\prime}>\mathrm{w}$, leading to 'uwuwa. At each step, the students have to cite the applicable rules and validate them by reference to changes elsewhere in the system. This example makes abundantly clear that the purpose of the exercises was to gain an understanding of the underlying rules, rather than to build a productive lexicon.

The preceding exercises took a known set of radicals as their point of departure. In other exercises, students are tasked with identifying the radicals within a given word, a procedure known as ištiqāq (splitting). One way of doing this is to apply a diminutive pattern fu' ayl (fu' aylil for words with four consonants), which has the property of reducing the number of root consonants to four, eliminating all augmented consonants. The name Hasan becomes Husayn, but the diminutive of the word 'ankabut /'ankabuwt/ (spider) is 'unaykib (little spider). Likewise, Muhammad from the root $h-m-d$ has a diminutive Humayd, and even a foreign name like 'Ibrähīm is reduced to Burayh, as if it is derived from a root $b-r-h$.

This exercise only works for speakers who are able to cite the correct form from the corpus of written Arabic. Some diminutives are unlikely to occur in this corpus and their derivation is purely theoretical. Grammarians took delight in thinking up ever-more-complicated problems, such as the diminutive of yawm al- 'ahad (Sunday), $b \vec{a}$ ' (the name of the letter $b$ ), or talațüna (thirty), forcing students to use their knowledge of the morphological rules in order to extract the root consonants. In this way, the nonce word 'uwuwa mentioned above could produce a diminutive 'uwayy, after the application of multiple rules.

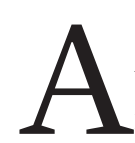

DIFFERENT KIND of exercise was connected with the phenomenon of diptosis. In principle, Arabic nouns have three cases, each represented by a separate ending. The word bayt (tent, house), for instance, has the nominative bayt-un, the genitive bayt-in, and the accusative bayt-an (the final $-n$ indicating indefiniteness). A number of so-called diptotic nouns have only two endings and lack the indefinite ending. The word 'ahmar (red), for instance, has the nominative 'ahmar- $u$ and the genitive or accusative 'ahmar-a.
The existence of diptotic words posed one of the greatest challenges for the grammarians. Their explanations turn around the notion of relative weight, which dominated their view of the language system. The grammarians ranged all elements in the language on a scale from light to heavy. The lightest, meaning the most unmarked, element is represented by an indefinite singular masculine generic noun, which by its lightness does not have the power to act as an operator, but is able to carry the full array of declensional endings marking its different functions in the sentence. Verbs, on the other hand, are rated as heavy, or marked, constituents that have the power to serve as operators, but are too heavy to carry any declensional endings. For a noun, any deviation from its primary noun-ness means that it becomes heavier, more verb-like, which may lead to the partial loss of its declensional rights.

Using a noun for the purpose of naming adds to its heaviness, so that naming may be used by teachers as a testing device. ${ }^{14}$ Some of their questions turn around existing names. The name 'Amr, for instance, is fully declined when given to a man, but if a woman is called by this name, it becomes too heavy and is only partially declined. Foreign names are fully declined when integrated in the Arabic lexicon, for instance Nüh (Noah), which has the same pattern as fül (beans). But when there is no fitting pattern in Arabic, the name's heaviness increases, and it becomes diptotic, as is the case for 'Ibrähìm (Abraham). Since verbs have no rights to declension, resemblance to a verbal pattern may also lead to diptosis. The noun 'iṣba' (finger) is fully declined, but when it is used as a proper name, its resemblance to an imperative like 'idhab (go away!) renders it too heavy, so that it becomes diptotic.

Matters become more complicated when imaginary names are used to test a student's understanding of the rules. The teacher may ask how to treat a verb, a particle, or even a sentence being used as a proper name. If someone were to be called by the passive verb Duriba (was hit), grammarians argue that this template is unique for verbs and therefore, when this form is transferred to the category of a noun by being used as a name, it becomes too heavy to be fully declined. ${ }^{15}$ But if one uses the passive verb Rudda (was returned) as a proper name, it is fully declined because this is similar to the nominal pattern fu ' la, as in kurra (ball). The imperative 'I dhab (go away!), on the other hand, has the same pattern as the noun 'ișba', but still receives diptotic declension when used as a name, because this pattern was not originally nominal. ${ }^{16}$ Grammarians were fond of citing increasingly fancy examples, including names like Allad̄i ra'aytu (the one I saw), Lā (no), or 'Itña-'ašara (twelve), which are unlikely to have ever been used as names. The point was not that students needed to know how to decline such proper names in real life but that, just like the exercises involving imaginary roots, the naming exercise was meant to test their skill in handling the appropriate rules. 
$\mathrm{T}$ HE ARABIC TERM for syntax (nahww) means grammar in general. Grammatical treatises traditionally started with syntax, followed by morphology, and ended with phonology. Knowledge of syntax represented the core of linguistic science. Students were trained to parse texts sentence by sentence, determining the syntactic function of each word. Some textbooks exemplify this by parsing the entire text of the 'Alfiyya. But parsing could also be trained with hypothetical sentences, created by grammarians for the specific purpose of challenging the students. In the ninth century, the grammarian al-Mubarrad includes in his al-Muqtadab (The Trimmed) a chapter entitled "Lengthy Problems to Examine the Learners."17 Most of the problems he cites involve excessive embedding. An English translation of one such sentence may give an idea of the kind of complications facing the students:

The one whose servant ate his food honored the one who hit with a whip the one who slandered the one who honored the one to whom the one in whose house your brother stayed had given a dirham. ${ }^{18}$

Students had to disentangle such sentences on the basis of the declensional endings.

A different type of test is known as al- ihbār bi-lladi $\bar{i}-$ predication with a relative. This procedure is similar to a clefting construction with a relative sentence, used in English to highlight a constituent. In the sentence "We were looking for the dog," for instance, the object may be highlighted by saying "What we were looking for was the dog." In Arabic, clefting is not commonly used for focusing purposes, but it does serve as a testing device. Students are given a sentence like 'a taytu zayd-an dirham-an (I gave Zayd a dirham), in which both the object and the recipient have an accusative ending. Clefting produces allad $\bar{\imath}$ ' a 'taytu-hu zayd-an dirham-un (What I gave Zayd is a dirham), in which the object turns into a predicate. This type of test was meant to familiarize students with the various syntactic roles in a sentence, in this case the agent, the object, and the recipient, by turning "I gave Zayd a dirham" into "The one who gave Zayd a dirham is me," "The one to whom I gave a dirham is Zayd," or "What I gave Zayd is a dirham."19

In actual speech, speakers commonly suppress parts of the message, leaving some of the declensional endings in the sentence stranded. To explain these endings, Arabic grammarians resorted to what was called taqdir (supposition), in order to reveal the underlying structure of the sentence. This procedure has nothing to do with restoring meaning, but serves to explain the governance relations in the surface message. When the surface structure is transparent, it does not need taqdìr, as in the sentence daraba zayd-un 'amr-an (Zayd hit 'Amr), where the verb daraba is the overt operator causing the nominative in the agent zayd and the accusative in the object 'amr. Often, however, elements are missing from the surface structure. A simple example is al-kilāb-a al-kiläb-a (The dogs, the dogs!), which does not contain a verb, but only a noun with an accusative ending. Here, the obvious explanation of the accusative ending consists in positing an elided verb "Beware!" in the underlying structure.

In more complicated sentences, it is less easy to determine which operators are responsible for a particular case ending. In 'amr-an darabtu-hu ('Amr, I hit him), the fronted object 'amr has an accusative ending, but it cannot be governed by the verb darabtu, which is already occupied with the object suffix -hu. The meaning of the sentence is perfectly clear, but in order to explain the case ending of the fronted object, a covert verb is needed: darabtu 'amr-an darabtu-hu (I hit 'Amr, I hit him). Establishing the taqdīr represents the apogee of theoretical reasoning in syntax, in which students demonstrate their ability to point out all overt and covert operators in the sentence.

$\mathrm{I}$ N GENERAL, Arabic grammatical theory focused on the formal rules of morphology and syntax, rather than on interpretation by semantic paraphrase. This is not to say that meaning was not important for the Arabic grammarians. On the contrary, they regarded meaningful communication as the main force driving all speech production. Students were supposed to be native speakers of Arabic and, as such, to be familiar with the meaning. Yet, even native speakers needed help with obscure or obsolete words in the texts, which had to be glossed in order to clarify their meaning. Outside the Arabic-speaking world, there was a much greater need for glossing. The simplest form of glossing consisted of marginal or interlinear translations of difficult words or phrases. When more and more words received their own gloss, eventually, the complete text was translated.

For purposes of glossing and translating, lexicographical tools were needed. Arabic lexicographers developed one of the richest lexicographical traditions in the history of linguistics. They systematically took inventory of all roots in an attempt to achieve ever-greater completeness in recording the words of the language. ${ }^{20}$ These efforts culminated in the fourteenth century with al-Fìrūzābādī's Tãj al- 'arūs (The Bride's Crown), which reached the staggering number of 120,000 entries. Such dictionaries were scholarly projects and definitely not intended as didactic tools. ${ }^{21}$ Their monolingual focus made them unsuitable for translating purposes, for which bilingual glossaries were needed. These were compiled within the same framework as the Arabic lexicographical tradition, including the $f-\mathrm{s}$ notation, even for languages that did not have the Arabic type of root structure. They were not intended for vocabulary training, because students were supposed to acquire their lexical knowledge in the course of reading and memorizing texts.

Within the Arabic-speaking world, bilingual glossaries were relatively rare. Berber was one of the exceptions. It was employed as an auxiliary language in teaching Arabic, but also as the language of elementary treatises on theology 
and other topics for beginning students. Arabic-Berber glossaries were compiled as early as the twelfth century and were usually thematic, in line with their function as translation tools. ${ }^{22}$

Outside the Arabic-speaking world, almost all indigenous languages in the regions where Islam was introduced gave rise to lexicographical tools, from simple word lists to complete dictionaries. Their main function was to facilitate the glossing and translating of Arabic texts for teaching purposes, but sometimes the lexicographers may have had ulterior motives in compiling their dictionaries. In the eleventh century, al-Kāshgharī used his Dīwān lugiàt at-Turk (Register of the Turkic Languages) to show that the Turkic languages were just as capable as Arabic of expressing complex thoughts, and possessed an equally rich lexicon. ${ }^{23}$ Early Persian lexicography, starting with the first Persian dictionary, Lugat-i Furs (Language of the Persians) by Asadī Țūsĩ in the eleventh century, was closely connected with the study of the rich lexicon of Persian poetry. ${ }^{24}$

Generally speaking, translators did not aim to produce literary or adaptive translations in their own language. Their sole aim was to provide as many word-to-word equivalents of the Arabic original as possible, showing the internal structure of each sentence of the text out of respect for the original. The resulting literal translations should not be regarded as a demonstration of any ineptness on the part of the translator. They generate a fairly peculiar kind of language, and one sometimes wonders how anyone could understand them. But stylistic qualities were never the issue, as the translations were meant to serve purely as a didactic aid to understand the original.

$\mathrm{W}$

ORD-BY-WORD translations not only helped students understand the original text, they also strengthened the implicit notion of an underlying similarity between the languages involved. Explicit proposals of a universal structure for all languages were not made until much later in Western linguistics, perhaps most poignantly so when Antoine Arnauld and Claude Lancelot published the first edition of their Grammaire générale et raisonnée in 1660. Underlying all languages, they claim, there exists a universal grammar. They all have the categories of subject, predicate, and object. When languages have case endings, speakers use them to indicate syntactic functions; when they do not, the same functions are indicated by different means. Arnauld and Lancelot believed that the choice depends on "the nature of the language." All languages can express the attribution of a property to a substance, but they do so in different ways, by an apposition, by an attributive participle, or by a relative sentence. In Latin one says video canem currentem and in French je vois un chien qui court; both propositions attribute the property of running to a dog. ${ }^{25}$
Throughout the history of the Arabic linguistic tradition, the claim of a universal structure of language was never made explicit in the manner of the Grammaire générale, but implicitly it constituted the basis for the grammarians' paradigm. In this framework, learning a new language meant learning how to set the parameters of the universal rules. It was the task of grammarians to teach their students the specific rules of the language they were learning.

The notion of a universal structure is not incompatible with a ranking scale of languages. For Arnauld and Lancelot it was obvious that French possessed a more logical way of expressing thought and a more natural word order. Yet it had to vie for first position with Latin and Greek. For Arabic grammarians, it was clear that Arabic possessed superior qualities, as it had been chosen by God for the last revelation. They were no doubt aware of other languages. After all, a good many of them were native speakers of other languages, starting from the founder of the discipline, Sibawayhi, whose native language was Persian. But these foreign languages could not compete with Arabic. Their underlying structure may have been identical to that of Arabic, but their way of expressing this structure was inferior. According to the tenth-century grammarian Ibn Făris, Arabic was unique in possessing a system of vowel endings that marked the grammatical function of a word within the sentence. ${ }^{26}$ Without this, he says, the listener would not be able to distinguish between an agent and an object in a sentence. He adds that, "some unreliable people claim that the philosophers [i.e., the Greeks] boasted declension and grammatical writings. But this is the kind of nonsense one does not waste one's time with.”

Some of the speakers of these languages begged to differ. In a debate that took place in 1026, the Syriac bishop Elias of Nisibis told a Muslim vizier that the Syriac language is vastly superior to Arabic precisely because it indicates syntactic functions with the help of a particle, rather than with declensional endings. Needless to say, his Arab interlocutor strongly disagreed..$^{27}$ Turkic grammarians were more modest in their claim, contenting themselves with a demonstration of the equality of their language with Arabic, but even they must have had a hard time convincing Arabic speakers.

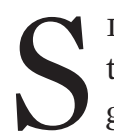

INCE THE DIFFERENCES between languages concern the formal expression of meaning, learning a language amounts to learning the particular realization of the universal rules in that language. Learning these rules takes place within an educational system that emphasizes memorization. Critics are correct in noting that this method ignores the communicative aspects of language learning, but then again, the goal was not to teach learners to speak Arabic spontaneously.

Modern applied linguistics is geared to the acquisition of both productive and receptive proficiency, but not to 
learned language acquisition. Yet this is what millions of students all over the world are engaged in at school. Catherine McBride points out that one half of school-going children in the world become literate in their second language before their native language; this second language is often a learned language they are not expected to use productively. ${ }^{28}$ They learn to read texts in this language through collective recitation. ${ }^{29}$ In the case of Arabic, the text most frequently recited is the Qur'an. Children learn to recite and write it, even before comprehending the content, which for some of them remains a mystery.

Dale Eickelman has analyzed the role of memorization in Islamic education. The rote learning system serves to guarantee the intact transmission of knowledge and leads to the canonization of a fixed set of texts. He speaks about the transmission of the religious sciences, but his conclusions apply equally well to the transmission of linguistic knowledge..$^{30}$ Still, such a system might be more flexible than its rigid nature suggests. Daniel Wagner's extensive fieldwork in Morocco and other Islamic countries focused on the impact of rote learning on the cognitive development of children. He did not find any trace of the stultifying effect that is often associated with this approach. ${ }^{31} \mathrm{Com}-$ pared to other types of learning, Qur' anic schooling with an emphasis on memorization turned out to have a positive effect on the children's serial memory skills, without affecting the development of other cognitive skills.

Wagner also followed the progress of a number of monolingual Berber-speaking children in Morocco after they began attending Arabic schools. The children grew up without exposure to spoken Arabic and became literate in Arabic during primary school. Pre-schooling in Qur' anic schools appeared to benefit them significantly more than Arabic-speaking children, who had already been exposed to spoken (Moroccan) Arabic at home. ${ }^{32}$

While many Berber children grow up in an Arabic-speaking environment, children in other Islamic countries are not exposed to spoken Arabic. Although there are few ethnographic or demographic studies of Arabic-language proficiency in Indonesia, Pakistan, and Iran, the general level of Arabic language skills in these countries does not seem to be high. Children learn to recite parts of the Qur'an, but for comprehension most of them depend on a translation in their own language. Only a few students progress to a more advanced stage, at which they are able to read Arabic texts by themselves. Even when traditional schools attempt to improve the linguistic level of students by introducing new methods of language teaching, ${ }^{33}$ reforms are hampered by a general lack of teachers and teaching materials. Nadia Selim identifies these difficulties as one of the principal reasons for the lack of success in teaching Arabic. ${ }^{34}$

Whether taught with traditional or modern didactic methods, Classical Arabic remains a learned language in the sense that it is not needed for communication.
Attempts to teach such a language for informal dialogue in a classroom are doomed to fail, and, at best, generate a highly stilted form of the language. Selecting the colloquial language as the target for teaching improves the ability to communicate, but clashes with the aim of teaching Arabic as the language of religion and science, which is naturally connected with written texts.

Learning by rote goes against the grain of modern didactic insights. Yet it cannot be denied that it is effective in teaching children to read and write. For a select few, this method acts as a bridge to a type of learning that does not differ greatly from the one that used to be current in European grammar schools. Classical Arabic may be a dead language in the sense that there are no native speakers, but it is very much alive in the sense that it plays an essential role in the cognitive development of students. The study of a learned language differs from normal second-language acquisition because of its focus on the analysis of written texts. Teaching this skill involves internalizing a set of grammatical rules and building a lexicon on the basis of words occurring in the texts.

The Arabic grammatical tradition found a novel way to reach this aim by systematically subjecting students to exercises that revolved around the application of rules, using both actual and made up forms. Having memorized the grammatical rules, students were tested constantly for their ability to handle them. Those gifted students who passed the entire course could apparently acquire a thorough understanding of the texts, bringing their learned language to life.

Kees Versteegh is Emeritus Professor of Arabic and Islam at the University of Nijmegen.

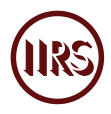

1. All of this changed rather rapidly in the 1970 s and 1980 s when every self-respecting school in the Netherlands built a language laboratory and threw away all grammar books, in the process reducing drastically the amount of time spent on the classical languages.

2. See Nicholas Ostler, Empires of the World: A Language History of the World (New York: HarperCollins, 2005). About Arabic as a learned language, see Kees Versteegh, "An Empire of Learning: Arabic as a Global Language," in Language Empires in Comparative Perspective, ed. Christel Stolz (Berlin: de Gruyter, 2015), 41-53.

3. Nico van den Boogert, The Berber Literary Tradition of the Sous, with an Edition and Translation of The Ocean of Tears by Muhammad Awzal (d. 1749) (Leiden: Nederlands Instituut voor het Nabije Oosten, 1997).

4. For the role of Timbuktu as an academic center, see Elias Saad, Social History of Timbuktu (Cambridge: Cambridge 
University Press, 1983). Swahili literary culture is treated by Clarissa Vierke, "Akhi patia kalamu: Writing Swahili Poetry in Arabic Script," in The Arabic Script in Africa: Studies in the Use of a Writing System, ed. Meikal Mumin and Kees Versteegh (Leiden: E. J. Brill, 2014), 319-39.

5. Nadia Selim, "Arabic, Grammar and Teaching: An Islamic Historical Perspective," International Journal of Islamic Thought 13, no. 1(2018): 80-89, doi:10.24035/ijit.06.2018.008. Sebastian Günther, "Be Masters in That You Teach and Continue to Learn: Medieval Muslim Thinkers on Educational Theory," Comparative Education Review 50, no. 3 (2006): 367-88, doi:10.1086/503881.

6. Selim, “Arabic, Grammar and Teaching," 85-87.

7. Sībawayhi, Kitāb (Bulaq, n.d.), I:247. The original has marartu bi-zaydin wa-'atānì 'ahūhu 'anfusu/ahumā. With the nominative 'anfusuhumā, the underlying structure is "both of them [are my friends]." With the accusative 'anfusuhumā, it is "[I mean] both of them."

8. Almog Kasher, "Early Pedagogical Grammars of Arabic," in The Foundations of Arabic Linguistics, vol. 3, The Development of a Tradition: Continuity and Change, ed. Georgine Ayoub and Kees Versteegh (Leiden: E. J. Brill, 2018), 146-66. Ramzi Baalbaki, "Grammar for Beginners and Ibn Hišām's Approach to Issues of ' $i$ 'rāb," in The Foundations of Arabic Linguistics, vol. 4, The Evolution of Theory, ed. Manuela Giolfo and Kees Versteegh (Leiden: E. J. Brill, 2019), 61-88.

9. The Arabic grammarians analyzed long vowels phonologically as combinations of a vowel and a glide, so that $\bar{u}$ and $\bar{\imath}$ are analyzed phonologically as /uw/ and /iy/, in which the glide counts as a consonant. The third glide, called 'alif, represented here with the sign $/{ }^{\prime \prime} /$, is an abstract phonological unit, introduced by the grammarians to account for the long vowel $\bar{a}$, analyzed by them as $/ \mathrm{a}^{\prime \prime} /$.

10. For a state-of-the-art summary, see Petr Zemánek, "Root," in Encyclopedia of Arabic Language and Linguistics, vol. 4, ed. Mushira Eid et al. (Leiden: E. J. Brill, 2009), 93-98.

11. Based on the many examples in the classic study by JeanFrançois Prunet, Renée Béland, and Ali Idrissi, "The Mental Representation of Semitic Words," Linguistic Inquiry 31, no. 4 (2000): 609-48, doi:10.1162/002438900554497.

12. Zajjājī, Majālis, ed. 'Abd al-Salām Muḥammad Hārūn (Kuwait: Wizārat al-'Irshād wa-l-'Anbā', 1962), 190. The correct answer is $y \bar{a}$ ' $\bar{a} z z u$ 'uzza (O confuser, confuse!).

13. Ibn Jinnī, Munșif, vol. 3, ed. 'Ibrāhīm Mușțafā and 'Abdallāh 'Amīn (Cairo: Mușțafā al-Bābī al-Ḥalabī, 1954), 106-109.

14. Michael Carter, "The Use of Proper Names as a Testing Device in Sībawayhi's Kitāb," in The History of Linguistics in the Near East, ed. Kees Versteegh, Konrad Koerner, and Hans-Josef Niederehe (Amsterdam and Philadelphia: J. Benjamins, 1983), 109-20.

15. Sỉbawayhi, Kitāb, II:13. Actually, the example is a bit more complicated: if the verbal form used as a proper name contains a covert pronoun forming a sentence, Duriba 'He was hit', it does not turn into a noun and can only be repeated verbatim as a proper name, without any declension at all.
16. Sībawayhi, Kitāb, II:4.

17. Mubarrad, Muqtạ̣ab, ed. Muḥammad Khāliq 'Uḍayma (Cairo: Dār al-Tahrīr, 1965-1968) I:22-28: masā 'il țiwāl yumtahanu bihā l-muta allimūna.

18. In the original sentence (al-d̄ariba l-šātima l-mukrima l-mu'tiyahu dirhaman al-qā'imu fì dārihi 'ahūka sawțan 'akrama l-'ākilu ta 'āmahu ġulāmuhu Zaydun 'Amran Hōalidin Bakran 'Abdallāhi 'ahūka), the relative sentences are represented by participial constructions, and at the end of the sentence a number of proper names with different case endings is added as appositions to the various actors in the sentence, which makes the exercise even more complex.

19. According to Carter, "The Use of Proper Names," 353, the purpose of this exercise is to establish the truth value of a sentence by systematically varying the predicate. See also Ramzi Baalbaki, The Legacy of the Kitāb: Sïbawayhi's Analytical Methods within the Context of the Arabic Grammatical Tradition (Leiden: E. J. Brill, 2008), 215-17.

20. A survey of this tradition is given by Ramzi Baalbaki, The Arabic Lexicographical Tradition from the 2nd/8th to the 12th/18th Century (Leiden: E. J. Brill, 2014).

21. This dictionary operated with an anagrammatic principle of ordering; it is called Kitāb al- 'ayn, because it starts with all roots containing the consonant ' ('ayn).

22. A special case is that of Hebrew-Arabic dictionaries. In the Islamic empire, Jews had adopted Arabic as their native tongue. They learned Hebrew but used it only for religious purposes. When they started to write grammars and dictionaries of Hebrew, they did so in Arabic, albeit in Hebrew script. These did not serve as tools to learn Arabic, but to learn the meaning of obscure Hebrew words, through Arabic.

23. Robert Ermers, Arabic Grammars of Turkic: The Arabic Linguistic Model Applied to Foreign Languages and Translation of 'Abū Hayyān's al- 'Andalusī's Kitāb al- 'idrāk li-Lisān al- 'Atrāk (Leiden: E. J. Brill, 1999), 16-20.

24. Solomon Baevskii, Early Persian Lexicography: Farhangs of the Eleventh to the Fifteenth Centuries (Leiden: E. J. Brill, 2007).

25. Grammaire générale et raisonnée ou la Grammaire de PortRoyal, ed. Herbert E. Brekle (Stuttgart-Bad Canstatt: Friedrich Frommann verlag, 1966), 70.

26. Ibn Fāris, al-Ṣạhibì fì fiqh al-lug̉a, ed. Moustafa Chouémi (Beirut: A. Badran, 1964), 42-43.

27. David Bertaina, "Science, Syntax, and Superiority in Eleventh-Century Christian-Muslim Discussion: Elias of Nisibis on the Arabic and Syriac Languages," Islam and Christian-Muslim Relations 22, no. 2 (2011): 197-207, doi:10.1 080/09596410.2011.560433.

28. Catherine McBride, Children's Literacy Development: A Cross-Cultural Perspective on Learning to Read and Write (London \& New York: Routledge, 2016), 171f.

29. McBride, Children's Literacy Development, 157, $168 \mathrm{f}$.

30. Dale Eickelman, "The Art of Memory: Islamic Education and Its Social Reproduction," Comparative Studies in Society and History 20 (1978): 485-516, doi:10.1017/s0010417500012536.

31. Daniel Wagner, Literacy, Culture, \& Development: Becom- 
ing Literate in Morocco (Cambridge: Cambridge University Press, 1993), 46-47, 58-59, 271-79.

32. Wagner, Literacy, 168-83.

33. As in some Salafi madrasas in Indonesia, see Noorhaidi Hasan, "The Salafi Madrasas of Indonesia," in The Madrasa in Asia: Political Activism and Transnational Linkages, ed.
Farish Noor, Yoginder Sikand, and Martin van Bruinessen (Amsterdam: Amsterdam University Press, 2008), 247-74.

34. Nadia Selim, "Muslim Societies' Ambivalence to Arabic: Reasons, Manifestations and Consequences," International Journal of Islamic Thought 11 (2017): 30-42, doi:10.24035/ ijit.11.2017.004. 